\title{
Fuzzy LOPA for the evaluation of accident scenarios and risk reduction measures in suppler manner
}

\author{
Hellas Mohamed Seddik ${ }^{(1)^{*}}$, Chaib Rachid ${ }^{(1)}$ \\ (1) Transportation Engineering, University of Constantine 1, Algeria \\ thsehsee@gmail.com, r3chaib@yahoo.fr
}

\begin{abstract}
The analysis and evaluation of risks by the LOPA method requires the presence of certain data and information on the various risk evaluation parameters such as, the frequencies of initiating events, the probabilities failures of the security barriers and also probability of ignition . This data is generally obtained from the history of the system analyzed. In the absence or lack of data on the state of the system, other sources such as databases and expert judgment are used. Despite the fact that the choice of data is made while respecting the adaptation of this data to the system studied, based on its history and on similar systems having the same mode of operation, it seems important to emphasize the fact that imperfections are not properly taken into account. linked to the data used by the various risk analysis methods including the LOPA method, the results are always uncertain and imprecise. To address such a problem, we use the "fuzzy LOPA" approach. As a case study, we used an operational industrial system which is a heater $\mathrm{H}-101$.
\end{abstract}

Keywords: Fuzzy LOPA, Uncertain and imprecise, Reduced frequencies consequence, Risk assessment.

\section{INTRODUCTION}

Quantitative Risk Analysis (QRA) [1; 2 and 3], also called probabilistic risk assessment, consists of identifying all the possible scenarios that can lead to undesirable events, assessing the severity of their consequences, calculating their probabilities of occurrence and assess them against the acceptability criteria established beforehand.

In the context of risk analysis and particularly during the application of dependability, qualitative, semi-quantitative and quantitative methods in industrial sectors, many problems are encountered, let us cite the problem of the unavailability of data related to different risk assessment elements and parameters.

And despite the fact that these data are established by experts with their relevant judgments and also provided by specialized databases, there will always be an inevitable subjectivity and uncertainty in the evaluation of the various parameters of the accident scenarios.

Still in the area of risk analysis, the linguistic descriptions used to assess the gravity of the consequences, even the vague risks in essence and provided by experts, are also another example of data that is difficult to analyze in an ordinary and conventional manner. For these and other reasons, it seems interesting to use representation models in the form of fuzzy sets and possibilistic. This for a good consideration of these problems.

In what follows, we present a fuzzy approach to LOPA taking into account uncertain and / or imprecise data. One of the possible representations of data by fuzzy intervals is proposed [4;5;6 and 7].

\section{METHODOLOGY}

The methodology is based on the fuzzy LOPA approach (Fig. 1). This approach makes it possible to assess the elements of an accident scenario and to measure risk reduction in a more flexible manner.

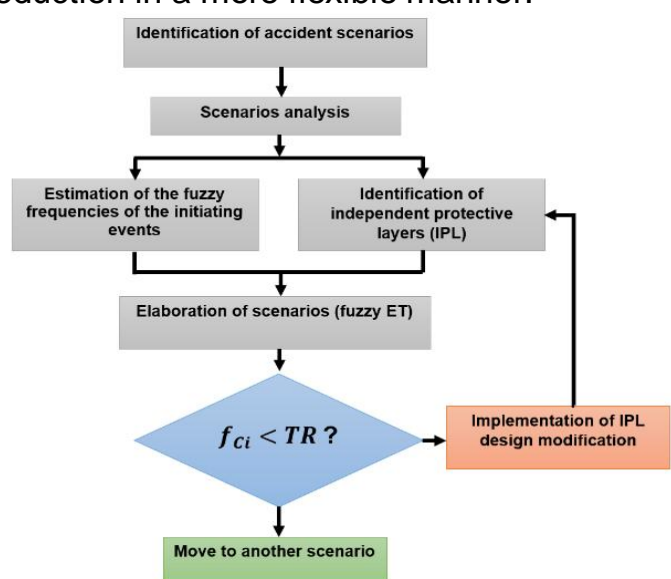

Fig 1. Methodology of working 


\section{PRESENTATION OF THE SYSTEM " HEATER H-101"}

Given the importance of the "Risks identification" part, we present the technical and functional description of the " heater $\mathrm{H}$ $101 "$ system Fig 2, and the analysis of the various accident scenarios.



Fig 2. Heater H-101 [8]

The heater $\mathrm{H}-101$ system includes:

- A radiation zone constituting the combustion chamber, internally lined with insulating refractory material, in which tubes are exposed to the flame and receive heat mainly by radiation from the combustion products.

- A convection zone, possibly garnished, installed at the outlet of the fumes from the combustion chamber. It consists of a bundle of tubes placed perpendicular to the direction of the fume.

- A tube bundle in the radiation zone and possibly in the convection zone.

- Two chimneys.

The principle role of the heater $\mathrm{H}-101$ is to produce light combustible gases which are mainly compounds of methane and ethane. The process for producing these gases is shown in Fig 3. The condensate from the bottom of column C-101 is sent by means of pumps $\mathrm{P}-101 \mathrm{~A} / \mathrm{B}$ to the heater $\mathrm{H}-101$ at 150 ${ }^{\circ} \mathrm{C}$ for reheating then the fluid leaving the $\mathrm{H}$ 101 heated to $180^{\circ} \mathrm{C}$ is returned to thecolumn as hot reflux in order to extract the light gases.

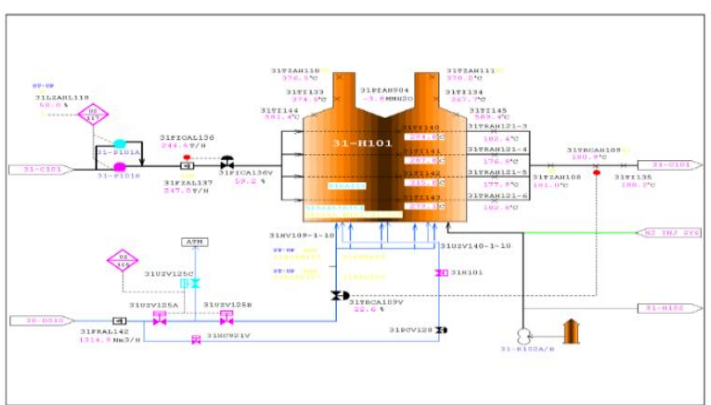

Fig 3. Pipe and instrumentation diagram of the $\mathrm{H}$ 101

\section{STRUCTURAL AND FUNCTIONALANALYSIS OF THE HEATER H -101SYSTEM}

Structural and functional analysis is an important step to gain a better understandingofthe " heater $\mathbf{H}-101 "$ system, its different subsystems and components. For more precision, we present the subsystem and its function:

- SS1: Supply circuit [heater alimentation].

- SS2: Draft subsystem [Ensures the arrival and circulation of air].

- SS3: Control subsystem [control of process parameters].

- SS4: Explosion Trappe [opens in case of pressure increase in the combustion chamber].

- SS5: Prevention subsystem [Ensures process security].

- SS6: protection subsystem [Fire mastery].

\section{ELABORATIONOF A HAZOP STUDY ON THE HEATER SYSTEM}

The interest of the application of the HAZOP method [9] is provided by a basic study allowing to identify the different causes and consequences of accident scenarios. It also makes it possible to envisage the various safety barriers which can prevent these accidents. All this information will be used in LOPA.

The Table 1 of HAZOP shows the different causes, consequences and safety barriers existing at the level of the heater $\mathrm{H}$ 101.

\section{SCENARIOS ANALYSIS}

The LOPA method inspires the different elements of its scenarios from the results provided by the HAZOP Table1 in the appendix.

The scenarios retained are: 
- Damage to the serpentine(fire) and unit shutdown.

- Release of fuel gas into the atmosphere, fire and process shutdown.

- High pressure inside the $\mathrm{H}-101$, explosion and process stop.

These scenarios are all of a severity high and are for the following events:

- Valve failure FICA-136V (IE1).

- Operator failure (erroneous manipulation of manual valves $\mathrm{HXC}$ 907V / 908V) (IE2)

- Failure of the safety valve (TOR) UZ125C (IE3)

\section{ESTIMATION OF THE FUZZY FREQUENCIES OF THE INITIATING EVENTS}

The fuzzy frequencies of the initiating events presented are taken from the literature $[10 ; 11 ; 12 ; 13$ and 14], represented by fig 4 and Table 2.



$\begin{array}{llll}\text { IE1 (per year) } & 1,0 \mathrm{E}-1 & 1.0 \mathrm{E}-1 & 1.0 \mathrm{E}-1 \\ \text { IE2 (per year) } & 1,0 \mathrm{E}-2 & 3.1 \mathrm{E}-2 & 1.0 \mathrm{E}-1 \\ \text { IE3 (per year) } & 1,0 \mathrm{E}-3 & 3.1 \mathrm{E}-3 & 1.0 \mathrm{E}-2\end{array}$

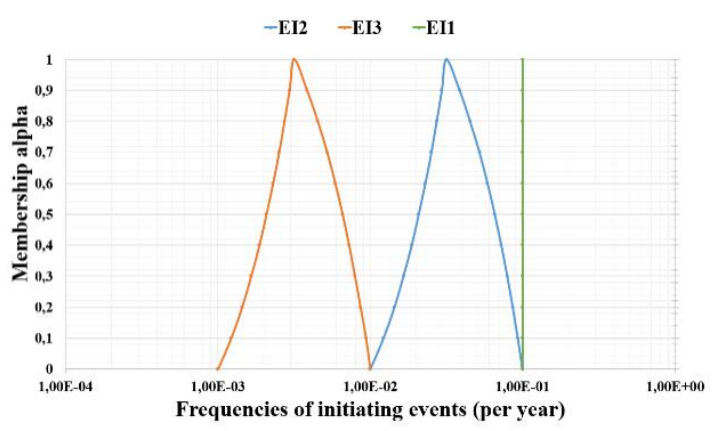

Fig. 4.Fuzzy frequencies of initiating events

The parameters $\mathrm{a}, \mathrm{b}$ and $\mathrm{m}$ are respectively the lower limit, the upper limit and the quadratic mean value of the fuzzy number.

\section{IDENTIFICATION OF INDEPENDENT PROTECTIVE LAYERS (IPL)}

Recall that among the security barriers identified beforehand by the HAZOP method, there are barriers that can be qualified IPL and those that are not.

The independent protective layers used in our study are as follows:

- Alarm \& Operator.

- Safety Instrumented Systems (SIS).

- Trappe.

Note that these probabilities are estimated by referring to several sources such as, standard IEC 61511 [15 and 16], a reference from the Center of Chemical Process Safety [CCPS, 2001] and data provided by the system designer [8].

The fuzzy probabilities failure on demand (PFD) for these protective layers are given in fig 5 and Table 3.

Table 3. Fuzzy PFD

$\begin{array}{cccc}\text { Fuzzy parameters } & \mathrm{a} & \mathrm{m} & \mathrm{B} \\ \begin{array}{c}\text { Operator response } \\ \text { to alarm }\left(\widetilde{P F D_{1}}\right) \\ \end{array} & 1.1 \mathrm{E}-1 & 1.1 \mathrm{E}-1 & 1.1 \mathrm{E}-1 \\ \mathrm{SIS}(\mathrm{PLC})\left(\widetilde{P F D_{2}}\right) & 1.0 \mathrm{E}-3 & 1.0 \mathrm{E}-2 & 1.0 \mathrm{E}-1 \\ \begin{array}{c}\text { Explosion Trappe } \\ \left(\widetilde{P F D_{3}}\right)\end{array} & 1.0 \mathrm{E}-3 & 3.1 \mathrm{E}-3 & 1.0 \mathrm{E}-2 \\ & & & \end{array}$

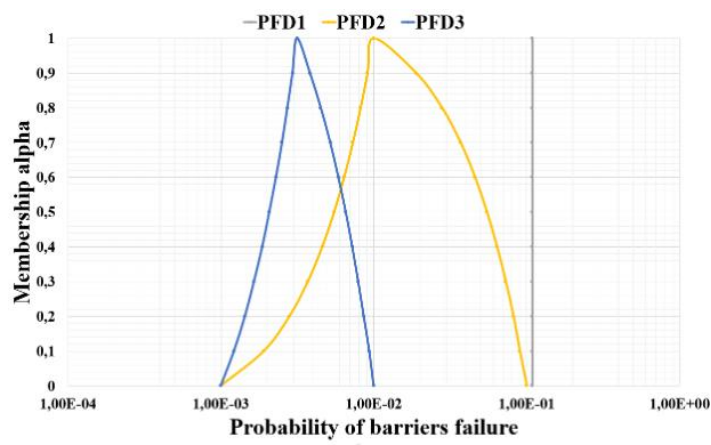

Fig.5 Fuzzy PFD

\section{ELABORATION OF SCENARIOS}

LOPA accident scenarios are represented by Event Trees (ET). The choice of this model allows us to clearly represent the sequence of events, by specifying their frequencies and therefore the frequency of the corresponding scenarios, Fig 6.

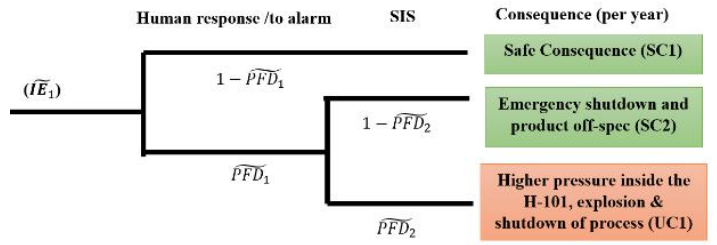

Scenario 1 




Scenario 2



Scenario 3

Fig .6 Fuzzy accident scenarios

\section{DETERMINATION OF THE FUZZY FREQUENCY CONSEQUENCES OF EACH ACCIDENT SCENARIO}

The confidence interval of the frequency consequence of each scenario is obtained using equation 1 by multiplying respectively the lower and upper bounds of the $\alpha$-cuts of the fuzzy numbers of the input parameters (EI, PFD). For accident scenarios with the same consequences, their total frequency is estimated by adding the frequencies of each scenario. The results of this analysis are presented in Fig 7 and Table 4

$\tilde{\mathrm{f}}_{\mathrm{ci}}=\alpha \cdot \mathrm{F}_{\mathrm{i} \alpha} \times \prod_{\mathrm{j}=1}^{\mathrm{j}} \alpha \cdot \mathrm{PFD}_{\mathrm{i} \alpha}^{\mathrm{j}} \times \prod_{\mathrm{k}=1}^{\mathrm{k}} \alpha \cdot(1-$ $\left.\operatorname{PFD}_{\mathrm{i}}^{\mathrm{k}}\right)_{\alpha}(1)$

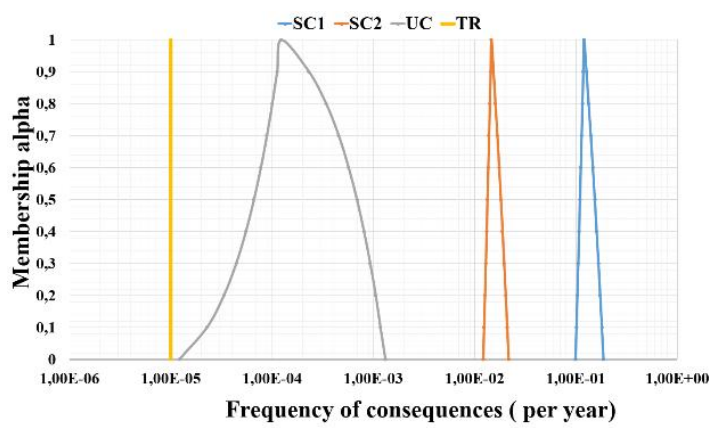

Fig.7 The frequencies of each scenario in fuzzy terms

The fuzzy frequency which is illustrated in fig 7 (UC) with all its values is superior to the maximum tolerable frequency therefore we must reduce it.

\section{EVALUATION OF ACCIDENTIAL SCENARIOS IN RELATION TO ACCEPTABILITY CRITERIA}

From the $F_{\text {np }}$ (frequency not protected) and $F_{\mathrm{t}}$ (frequency of tolerable risk), the IEC 61508 [9] standard details how this method can be used to determine the SIL (safety Integrity level) of a low-demand safety function. The average probability of failure on demand $\left(P F D_{\text {avg }}\right)$ is determined according to the procedure illustrated in Fig8. In this figure, it is clearly highlighted that the initial risk (risk inherent in the operating system, qualified as EUC -Equipment Under Controlin the standard) is reduced to a tolerated risk, through the $P F D_{\text {avg }}$ factor. The value of this factor is limited by the reduction of the minimum risk to be brought that is to say by the inverse of the Risk Reduction Factor (RRF). Taking into account the value of $P F D_{\text {avg }}$ retained, the safety integrity level (SIL) of the function can then be determined from Table 7.

This step consists of evaluating the estimated accident scenarios compared to the acceptability criteria that have been set beforehand in order to judge the acceptability of these scenarios. Each scenario is evaluated before and after the establishment of IPL.

Table 7. SIL table for demand and continuous mode of operation [16]

\begin{tabular}{|c|c|c|}
\hline \multirow{2}{*}{$\begin{array}{l}\text { safety } \\
\text { Integrity } \\
\text { level } \\
\text { (SIL) }\end{array}$} & Low demand & $\begin{array}{l}\text { Continuous mode or } \\
\text { high demand }\end{array}$ \\
\hline & $\begin{array}{l}\text { probability of } \\
\text { failure on demand }\end{array}$ & $\begin{array}{l}\text { Probability of } \\
\text { dangerous failure per } \\
\text { hour (PFH) }\end{array}$ \\
\hline SIL 4 & $\begin{array}{l}10^{-5} \leq \text { PFD avg } \\
<10^{-4}\end{array}$ & $10^{-9} \leq \mathrm{PFH}<10^{-8}$ \\
\hline SIL 3 & $\begin{array}{l}10^{-4} \leq \text { PFD avg } \\
<10^{-3}\end{array}$ & $10^{-8} \leq \mathrm{PFH}<10^{-1}$ \\
\hline SIL 2 & $\begin{array}{l}10^{-3} \leq \mathrm{PFD}_{\text {avg }} \\
<10^{-2}\end{array}$ & $10^{-1} \leq \mathrm{PFH}<10^{-6}$ \\
\hline SIL 1 & $\begin{array}{l}10^{-2} \leq \text { PFD avg } \\
<10^{-1}\end{array}$ & $10^{-6} \leq \mathrm{PFH}<10^{-5}$ \\
\hline
\end{tabular}

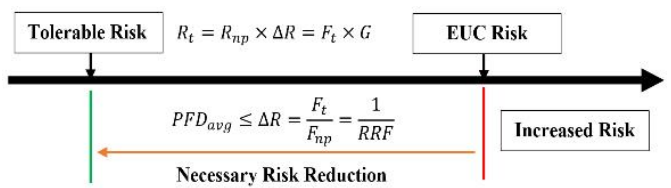

Fig .8 Risk reduction by using a low-demand security function

Referring to the accident scenario with frequencies ranging from "almost intolerable" to "tolerable", we have seen how the PFD 
required varies according to the difference between the fuzzy frequency (UC) and the tolerable Risk (TR) (fig. 9 and table8), in this context we propose the following barrier:

- SIL 2 if RRF: $\alpha=[0$ (lower); 0.2 (lower)].

- SIL 1 if RRF: $\alpha=[0.2$ (lower); 0.8 (upper)].

- No SIL if RRF: $\alpha=[0.8$ (upper; 0 (upper)].

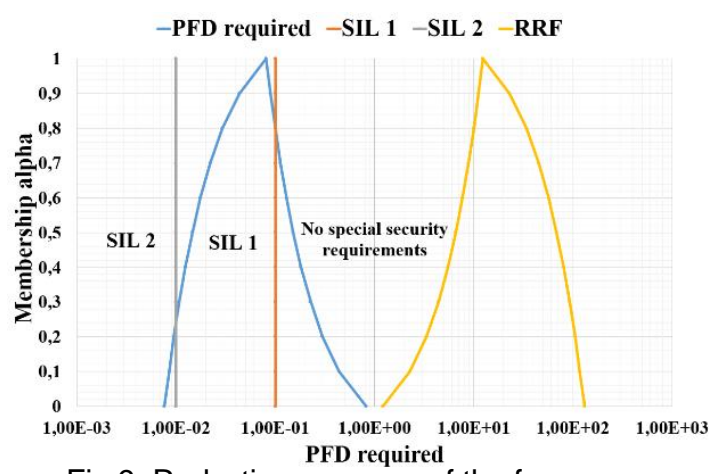

Fig 9. Reduction measure of the frequency consequences

Table 8. Reduction measure of the frequency consequences

\begin{tabular}{ccc}
$\alpha$-level & \multicolumn{2}{c}{ RRF } \\
0 & $1,21 \mathrm{E}+00$ & $1,31 \mathrm{E}+02$ \\
0.1 & $2,27 \mathrm{E}+00$ & $1,17 \mathrm{E}+02$ \\
0.2 & $3,33 \mathrm{E}+00$ & $1,05 \mathrm{E}+02$ \\
0.3 & $4,41 \mathrm{E}+00$ & $9,27 \mathrm{E}+01$ \\
0.4 & $5,50 \mathrm{E}+00$ & $8,05 \mathrm{E}+01$ \\
0.5 & $6,60 \mathrm{E}+00$ & $6,85 \mathrm{E}+01$ \\
0.6 & $7,72 \mathrm{E}+00$ & $5,68 \mathrm{E}+01$ \\
0.7 & $8,86 \mathrm{E}+00$ & $4,53 \mathrm{E}+01$ \\
0.8 & $1,00 \mathrm{E}+01$ & $3,40 \mathrm{E}+01$ \\
0.9 & $1,12 \mathrm{E}+01$ & $2,30 \mathrm{E}+01$ \\
1 & $1,23 \mathrm{E}+01$ & $1,23 \mathrm{E}+01$
\end{tabular}

\section{Conclusion}

The risk reduction problem presented by an industrial system remains basic of preoccupations of risk analysts. Reducing a risk to an acceptable or tolerable level, by using several safety barriers, amounts to evaluate the effectiveness of these barriers. To do this and for more precision in risk assessment and in particular in high-risk industries, it is always necessary to use new approaches resulting from fuzzy and possibilistic techniques.

\section{References}

[1] MS .Hellas, R .Chaib,C. Mourad, (): "QRA approach to model consequences of fireball accident scenarios and VCE case LPG storage tank In Aminas Algeria". Fourth International Conference on Energy Materials Applied Energetics and Pollution, , Vol. 3, , Constantine, Algeria,pp.1737-1744.2018.

[2] ISBN: 978-9931-9229-6-4

[3] MS.Hellas, R.Chaib, I .VERZEA, "Quantitative Risk Analysis Detailed Study of Thermal and Overpressure Risks Case Study". Journal of RECENT, Vol. 19, no. 3 (56), pp. 128-136,2018.

[4] http://www.recentonline.ro/056/HellasR56.pdf

[5] MS. Hellas, R. Chaib, "quantitative risk analysis: case of LPG Constantine Algeria" 4th international conference on advances in mechanical engineering Istanbul 2018 (ICAME2018), vol. 3, pp. 279- 287,2018.

[6] ISBN 978-605-9546-13-3,

[7] MS. Hellas, R. Chaib, I .VERZEA,"Artificial intelligence treating the problem of uncertainty in quantitative risk analysis (QRA)“, journal of engineering, design and technology, Vol. 18 No. 1, pp. 40-54. https://doi.org/10.1108/JEDT-03-2019$\underline{0057}$

[8] L. Zadeh, " Fuzzy sets ", Information and Control, vol. 8, pp. 338-353, 1965.

[9] L. Zadeh, "Fuzzy sets as a basis for a theory of possibility ", Fuzzy Sets and Systems, vol. 1, pp. 3-28, 1978.

[10] Dubois, H. Prade, 'Ranking Fuzzy Numbers in the Setting of Possibility Theory', Inf. Sci. 30,183-224, 1983.

[11] SONATRACH, SONATRACH DP HRM document. 2008.

[12] IEC 61882, Hazard and operability studies (HAZOP studies) - application guide. International Electrotechnical
Commission

[13] (IEC).2001.

[14] http://www.onr.org.uk/documents/tolerability.p df

[15] ICSI, Working group "Frequency of initiating events and availability of protection and prevention barriers, Institute for a Culture of Industrial Security version of July 11, 2006

[16] CCPS, Layer Of Protection Analysis, simplified process assessment, Center for Chemical Process Safety of the American Institute for Chemical Engineers, New York, 2001. 
[17] OREDA , SINTEF. Offshore Reliability Data Handbook (OREDA), 4th ed., DNV Technica, Norway,2002.

[18] CCPS, Guidelines for Process Equipment Reliability Data with Data Tables, AIChE, New York, NY.1989.

[19] INERIS DRA-41, Technical Support for the Implementation of PPRTs, National Institute for the Industrial Environment and Risks.2004

[20] IEC 61511 Standard, Functional safetySafety instrumented systems for the process industry sector-, Parts 1-3, First edition, 2003.

[21] IEC 61508, Functional safety of electrical / electronic / programmable electronic safety-related systems. IEC 61508-1 to 7. Geneva, Switzerland, IEC, International Electrotechnical Commission.2000. 


\section{Appendix}

Table 1. HAZOP Presentation Sheet

\begin{tabular}{|c|c|c|c|c|c|c|}
\hline & $\begin{array}{l}\text { Guide } \\
\text { word }\end{array}$ & Element & Deviation & Possible causes & Consequences & Protections \\
\hline \multirow[t]{3}{*}{1} & \multirow[t]{3}{*}{$\begin{array}{l}\text { No / } \\
\text { Less }\end{array}$} & \multirow[t]{3}{*}{$\begin{array}{l}\text { Flow of } \\
\text { condensate }\end{array}$} & \multirow[t]{3}{*}{ No/Less flow } & $\begin{array}{l}\text { Failure of the valve } \\
\text { FICA-136V }\end{array}$ & $\begin{array}{l}\text { No liquid in } \mathrm{H}- \\
101 \text {, damage } \\
\text { of serpentine (fire) } \\
\text { \& process shutdown }\end{array}$ & $\begin{array}{l}\text { - Operators } \\
\text { - FICAL-136 } \\
\text { - FZL-137 }\end{array}$ \\
\hline & & & & $\begin{array}{l}\text { failure operation of } \\
\text { FICA-136V }\end{array}$ & $\begin{array}{l}\text { No liquid in } \mathrm{H}-101 \text {, } \\
\text { damage of serpentine } \\
\text { (fire) \& process shutdown }\end{array}$ & $\begin{array}{l}\text { - FICAL-136 } \\
\text { - FZL-137 }\end{array}$ \\
\hline & & & & $\begin{array}{l}\text { failure manipulation on } \\
\text { one of the inlet heater } \\
H-101 \text { manual valves. }\end{array}$ & $\begin{array}{l}\text { No debit in one } \\
H-101 \text { passes, } \\
\text { high temperature, } \\
\text { damage of serpentine } \\
\text { (fire) \& process shutdown }\end{array}$ & $\begin{array}{l}\text { - FI-138 } \\
\text { - TRAH-121-3 } \\
\text { - FICAL-136 } \\
\text { - FZL-137 }\end{array}$ \\
\hline 2 & More & \multirow{2}{*}{$\begin{array}{l}\text { Temperature } \\
\text { of condensate }\end{array}$} & $\begin{array}{l}\text { More of the } \\
\text { temperature }\end{array}$ & $\begin{array}{l}\text { failure operation of the } \\
\text { valve } \\
\text { TRCA-109V, } \\
\text { combustion } \\
\text { important in } \\
H-101\end{array}$ & $\begin{array}{l}\text { High temperature at the } \\
\text { exit of } \mathrm{H}-101, \text { damage of } \\
\text { serpentine (fire) \& process } \\
\text { shutdown }\end{array}$ & $\begin{array}{l}\text { - TI-135 } \\
\text { - TRAH-121-3 6 } \\
\text { - TRCAH-109 } \\
\text { - TZH-108 }\end{array}$ \\
\hline 3 & Less & & $\begin{array}{l}\text { Less of the } \\
\text { temperature }\end{array}$ & $\begin{array}{l}\text { failure operation from } \\
\text { TRCA-109V, weak } \\
\text { combustion in } \mathrm{H}-101\end{array}$ & $\begin{array}{l}\text { Low temperature at } \\
\text { exit from } \mathrm{H}-10 \text {, possible } \\
\text { passage of product to } \\
\text { OFF-SPEC }\end{array}$ & $-\mathrm{TI}-135$ \\
\hline \multirow[t]{5}{*}{4} & \multirow[t]{3}{*}{$\begin{array}{l}\text { No } \\
\text { /Less }\end{array}$} & \multirow{5}{*}{$\begin{array}{l}\text { Flow ofgas } \\
\text { combustible }\end{array}$} & \multirow{5}{*}{$\begin{array}{l}\text { No / Less } \\
\text { flow }\end{array}$} & $\begin{array}{l}\text { failure operation } \\
\text { of the valve UZ- } \\
125 / B \text { (closed) }\end{array}$ & $\begin{array}{l}\text { No fuel gas for } \mathrm{H}-101, \text { low } \\
\text { fuel gas pressure, low } \\
\text { temperature at the outlet } \\
\text { of } \mathrm{H}-101, \text { possible } \\
\text { passage of product to } \\
\text { OFF-SPEC }\end{array}$ & $\begin{array}{l}\text { - PAL-126 } \\
\text { - FRAL-142 } \\
\text { - TRCA-109 }\end{array}$ \\
\hline & & & & $\begin{array}{l}\text { failure operation } \\
\text { of the valve UZ- } \\
125 / C \text { (open) }\end{array}$ & $\begin{array}{l}\text { No fuel gas for } \mathrm{H}-101 \text {, low } \\
\text { fuel gas pressure, low } \\
\text { temperature at the outlet } \\
\text { of } \mathrm{H}-101 \text {, possible } \\
\text { passage of product to } \\
\text { OFF-SPEC }\end{array}$ & \multirow[t]{2}{*}{$\begin{array}{l}\text {-PAL-126 } \\
\text { - PZL-127 } \\
\text { - FRAL-142 } \\
\text { - TRCA-109 }\end{array}$} \\
\hline & & & & & $\begin{array}{l}\text { Release of fuel gas in the } \\
\text { atmosphere, possible } \\
\text { explosive \& process } \\
\text { shutdown }\end{array}$ & \\
\hline & \multirow[t]{2}{*}{$\begin{array}{l}\text { No } \\
\text { /Less }\end{array}$} & & & $\begin{array}{l}\text { failure manipulation on } \\
\text { the manual valve at the } \\
\text { inlet / outlet of TRCA- } \\
109 \mathrm{~V} \text { (closed) }\end{array}$ & $\begin{array}{l}\text { No fuel gas for } \mathrm{H}- \\
101, \text { low pressure } \\
\text { fuel gas, low temperature } \\
\text { at the outlet of } \mathrm{H}-101, \\
\text { possible passage of } \\
\text { product to } \\
\text { OFF-SPEC }\end{array}$ & $\begin{array}{l}\text { - PAL-126 } \\
\text { - PZL-127 } \\
\text { - FRAL-142 } \\
\text { - TRCA-109 }\end{array}$ \\
\hline & & & & $\begin{array}{l}\text { failure operation } \\
\text { of the valve TRCA- } \\
109 \mathrm{~V} \text { (closed) }\end{array}$ & $\begin{array}{l}\text { No fuel gas for } \mathrm{H} 101 \text {, low } \\
\text { fuel gas pressure, low } \\
\text { temperature at the outlet } \\
\text { of } \mathrm{H}-101 \text {, possible } \\
\text { passage of product to } \\
\text { OFF-SPEC }\end{array}$ & $\begin{array}{l}\text {-PAL-126 } \\
\text {-PZL-127 } \\
\text { - FRAL-142 }\end{array}$ \\
\hline
\end{tabular}


Table 4. The frequencies of fuzzy consequences

\begin{tabular}{|l|l|l|l|l|l|l|}
\hline \multicolumn{1}{|c|}{$\alpha$-level } & \multicolumn{2}{|c|}{ SC1 } & \multicolumn{2}{c|}{ SC2 } & \multicolumn{2}{c|}{ UC1 } \\
\hline 0 & 0.000891 & 0.0891 & 0.000109 & 0.010791 & 0.000000109 & 0.000109 \\
\hline 0.1 & 0.001087 & 0.08296101 & 0.000133 & 0.010054 & $2.53992 \mathrm{E}-07$ & $9.21 \mathrm{E}-05$ \\
\hline 0.2 & 0.001283 & 0.07690221 & 0.000157 & 0.009327 & $4.41058 \mathrm{E}-07$ & $7.7 \mathrm{E}-05$ \\
\hline 0.3 & 0.00147 & 0.07075431 & 0.000179 & 0.008587 & $6.67244 \mathrm{E}-07$ & $6.31 \mathrm{E}-05$ \\
\hline 0.4 & 0.001666 & 0.06469551 & 0.000203 & 0.007857 & $9.39656 \mathrm{E}-07$ & $5.06 \mathrm{E}-05$ \\
\hline 0.5 & 0.001853 & 0.05854761 & 0.000225 & 0.007115 & $1.24923 \mathrm{E}-06$ & $3.94 \mathrm{E}-05$ \\
\hline 0.6 & 0.002049 & 0.05248881 & 0.000249 & 0.006383 & $1.60699 \mathrm{E}-06$ & $2.95 \mathrm{E}-05$ \\
\hline 0.7 & 0.002245 & 0.04643001 & 0.000273 & 0.00565 & $2.00791 \mathrm{E}-06$ & $2.1 \mathrm{E}-05$ \\
\hline 0.8 & 0.002432 & 0.04028211 & 0.000295 & 0.004906 & $2.44305 \mathrm{E}-06$ & $1.38 \mathrm{E}-05$ \\
\hline 0.9 & 0.002628 & 0.0343926 & 0.000319 & 0.004191 & $2.92932 \mathrm{E}-06$ & $7.91 \mathrm{E}-06$ \\
\hline 1 & 0.002816 & 0.02816451 & 0.000341 & 0.003435 & $3.4444 \mathrm{E}-06$ & $3.44 \mathrm{E}-06$ \\
\hline
\end{tabular}

